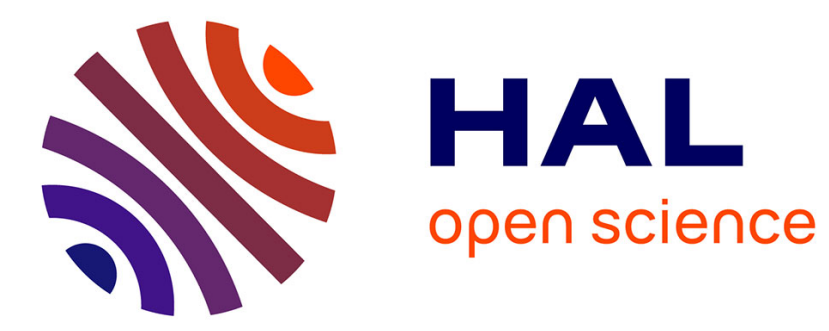

\title{
Hyladelphys kalinowskii in French Guiana: new observations and first notes on its nesting biology \\ Francois Catzeflis
}

\section{To cite this version:}

Francois Catzeflis. Hyladelphys kalinowskii in French Guiana: new observations and first notes on its nesting biology. Mammalia, 2017, 82 (5), pp.431-437. 10.1515/mammalia-2017-0107 . hal-01836214

\section{HAL Id: hal-01836214 \\ https://hal.umontpellier.fr/hal-01836214}

Submitted on 12 Jul 2018

HAL is a multi-disciplinary open access archive for the deposit and dissemination of scientific research documents, whether they are published or not. The documents may come from teaching and research institutions in France or abroad, or from public or private research centers.
L'archive ouverte pluridisciplinaire HAL, est destinée au dépôt et à la diffusion de documents scientifiques de niveau recherche, publiés ou non, émanant des établissements d'enseignement et de recherche français ou étrangers, des laboratoires publics ou privés. 
Accepted 21-november-2017

Manuscript ID: Mammalia.2017.0107 - Revised ms 06 october 2017;

changes made according to reviewers corrections \& suggestions

Dedicated to the memory of Peter Vogel (1942 - 2015)

Hyladelphys kalinowskii in French Guiana : new observations and first notes on its nesting biology.

Francois CATZEFLIS

Institut des Sciences de l’Evolution, UMR-5554 CNRS, Faculté des Sciences, Université de Montpellier, 34095 Montpellier, France

Francois.catzeflis@univ-montp2.fr

Running title:

new observations of Hyladelphys and its nests in French Guiana 


\section{$\underline{\text { Abstract }}$}

A series of 14 new observations of Hyladelphys kalinowskii (Didelphidae) provides novel natural history information about this rare Neotropical opossum, which appears to occur throughout French Guiana, from highly degraded forest patches of the littoral zone to large tracks of pristine primary forests in the interior. Six nests were found containing one to several individuals, including females with suckling young. It appears that the components (dry leaves, small twigs) of some nests are glued together with a whitish cement of unknown origin. Including previously reported records, a total of 18 individuals of $H$. kalinowskii have now been caught or observed in French Guiana. External and cranial measurements of five adult specimens are tabulated.

Keywords : opossum, artificial nest, roost, Didelphidae, South America, natural history

\section{Introduction}

The tiny Neotropical marsupial Hyladelphys kalinowskii (Hershkovitz, 1992) is a rare opossum, which was redescribed - and erected into a new genus - by Voss et al. (2001) after the capture of three individuals from Paracou, French Guiana. Previously, the species was only known by four other specimens (3 from Peru, 1 from Guyana), and many aspects of its biology are still completely unknown. Subsequently, a few more H. kalinowskii were reported from Brazil (1 in Amapa State by da Silva et al., 2013; 1 in Amazonas State by Astua, 2006), French Guiana (1 by Astua, 2006), and Peru (1 in Hice, 2001; 1 in Solari et al., 2001), bringing the total known sample to a dozen individuals. 
Hyladelphys is such a beautiful - and externally distinctive - small opossum that it can hardly be mistaken for other similar-sized didelphid species. The field naturalists who shared their observations for this study noted many of its externally diagnostic traits (Jansa and Voss, 2005), including a dark circumocular mask that extends from the mystacial region to the base of the ear on each side of the face; very large, membranous pinnae; a broad median streak of paleorange rostral fur between the eye rings; reddish dorsal pelage; and pure white ventral pelage. Here we report 14 new observations of this secretive and diminutive opossum, which appears to live in a variety of different forested habitats in French Guiana. In particular, we describe the globular nests of dry leaves in which this species has been found on several occasions. We also present morphometric data for a few external and cranial variables of five adult specimens from French Guiana and Amapá (Brazil).

\section{Materials and methods}

Thanks to correspondence exchanged with numerous field scientists and well-trained amateur naturalists working in French Guiana, the author was able to gather 14 independent observations of Hyladelphys kalinowskii, which are summarized here.

For each reported observation (which is accompanied by author's name), the original correspondence - mainly e-mails - exchanged with the observer has been kept (available upon request). Although observations were haphazardly acquired (i.e., not the product of systematic surveys or focussed searches), most are accompanied by high-quality photographs and/or a sufficiently detailed description of the animal(s) such that identifications could be made with confidence.

External measurements were taken as described in Voss et al. (2001), either from freshly killed animals or from collector’s field notes (for the Amapá specimens). Craniodental measurements were taken on the cleaned skulls with dial calipers (accurate to $0.05 \mathrm{~mm}$ ) as illustrated by Voss et al. (2001: figure 7). By « adult », we consider individuals with their four molars all erupted 
and with their definitive (permanent) third premolar. All vouchered specimens are kept as dry cleaned skull and wet body in ethanol. Abbreviations for institutions housing specimens are: MHNG = Museum d'Histoire Naturelle de la ville de Genève (Geneva, Switzerland) ; IEPA = Instituto de Pesquisas Científicas e Tecnológicas do Estado do Amapá (Macapa, Brasil) ; ISEM-V = Institut des Sciences de l'Evolution de Montpellier, Montpellier University (Montpellier, France).

\section{$\underline{\text { Results }}$}

The reported observations (numbered 1 to 14) are organized by ecosystems: first in the large blocks of primary forests from the interior of the country, then in secondary forests, and lastly in the highly fragmented forested patches in the coastal zone of northern French Guiana.

\section{Les Nouragues field station (municipality of Regina) $04^{\circ} 05^{\prime} 30^{\prime \prime N} ; 52^{\circ} 42^{\prime} 00^{\prime \prime} \mathrm{W}$ :}

(1) 2 May 2009: in a well drained primary forest: a globular nest (Figure 1) of dry leaves (whole tree-leaves or fragments thereof) interlaced with small twigs affixed to a palm-tree; the nest components appeared to be glued to each other by a whitish dried substance. Several leaves of the nest had been forced through a spine of the palm-tree. The nest had an external diameter of 7 to $9 \mathrm{~cm}$, and was situated ca $1.6 \mathrm{~m}$ above the ground, in the center of the spiny stalks of the palm-tree. An adult male, captured while escaping from the nest, was kept alive for a few days by Philippe Gaucher and then preserved as a voucher (ISEM-V-2632) and deposited at Montpellier University. When in captivity, the animal was successfully fed with small grasshoppers (Orthoptera) and ripe berries of Melastomataceae spp.

(2) 2 June 2009: in an artificial nestbox (a tubular section of bamboo, with inner diameter of ca $4.5 \mathrm{~cm}$ ) for birds, at a height of $1.8 \mathrm{~m}$ above the ground along a narrow trail in well-drained primary forest. Four individuals (apparently of similar size and aspect) were sleeping together 
in the wooden nestbox; the observer (Philippe Gaucher) took a picture, allowing a positive identification of Hyladelphys kalinowskii. The animals were not disturbed further; thus, the age and sex composition of the group is not known. This observation was made about $500 \mathrm{~m}$ from the nest found on 2 May 2009.

\section{La Trinité Natural Reserve (municipality of Saint-Elie) $04^{\circ} 35^{\prime} 53^{\prime \prime N}$; 5324'37"W:}

(3) 3 October 2010: in well-drained primary forest in the foothills of a small inselberg mountain, this nest consisted of a hemispherical cup of dry leaves, tightly attached to each other by whitish cement, in the hollow center of the stump of a broken dead tree at a height of ca. $1 \mathrm{~m}$ above the ground. The nest (with an external diameter ca. 10 to $12 \mathrm{~cm}$ ) was spherical, the entrance was closed and not apparent; when disturbed by Sylvain Pincebourde and colleagues, an adult female (enlarged nipples are visible on photographs) carrying a single juvenile on its back escaped. The opossum then moved by jumping two meters onto a small tree, where it was easily photographed (Figure 2). Sylvain Pincebourde (e-mail dated 4 January 2011) emphasized that most of the leaves composing the nest were glued to each other, quite unlike local bird nests with similar leaf components.

(4) 16 December 2010: in well drained primary forest: a globular nest (external diameter of ca. 8 to $10 \mathrm{~cm}$ ) of dry leaves interlaced with small twigs was affixed to a palm-tree stalk at a height of ca. $3 \mathrm{~m}$ above the ground; this nest contained one adult with 2 to 4 very small juveniles covered by spare pelage. The observer (Marguerite Delaval) recognized the species from photographs previously taken by her colleagues (on 3 October 2010; see above). The sites at which these observations were made (on 3 October and 16 December) are ca. $1.5 \mathrm{~km}$ apart. The nest was examined in detail and photographed; apparently, all of the dry leaves and twigs that made up the nest were glued together and to the spines of the palm-tree by whitish cement (Figure 3). This cement remains intact and apparently unchanged on parts of the nest which 
have been preserved in 90\% ethanol, under reference T-3377 at ISEM (University of Montpellier).

(5) 2 May 2013: in well-drained primary forest at $450 \mathrm{~m}$ above sea level: a spherical nest (largest diameter of ca. $10 \mathrm{~cm}$ ) built in an epiphytic bromeliad (Vriesea splendens; Bromeliaceae) about $1.5 \mathrm{~m}$ above the ground on the trunk (diameter ca $45 \mathrm{~cm}$ ) of an unidentified tree (Figure 4). No entrance was apparent, and all of the dry tree-leaves composing the nest seemed to be glued to each other. When the observer (Antoine Fouquet) gently opened the nest (Figure 5), he noticed and photographed one adult with 2 to 3 well haired juveniles (the nest was immediately left undisturbed; thus, the exact number of young could not be ascertained). This location was ca. $300 \mathrm{~m}$ from the one of 3 October 2010.

\section{Other localities in primary rainforests}

(6) 4 March 2014: in central French Guiana, along the trail between Saül and Mont Galbao (0336'18"N; 53¹4'21"W; municipality of Saül), three people who were clearing their way with machetes cut a tree holding a large globular nest (external diameter 15 to $17 \mathrm{~cm}$ ) of dry leaves and shredded bark, which fell to the ground (Figure 6). The nest components were not glued to each other; an adult carrying two well-haired juveniles on its back exited the nest and was photographed by Rémy Pignoux and Christian Moulin.

(7) 28 February 2015 : in the transition forest $\left(02^{\circ} 17^{\prime} 18^{\prime \prime} \mathrm{N} ; 4^{\circ} 31^{\prime} 22^{\prime \prime} \mathrm{W}\right)$ between lowland terra firme primary forest and upland montane forest of the Mitaraka inselberg (municipality of Maripasoula). The photographer Yann Chavance and colleagues observed, caught, photographed, and released an adult with four well haired juveniles on its back, which was found walking along a liana about $2 \mathrm{~m}$ above the ground. When released, this female -with her four young on her back - jumped to a small, almost vertical liana, and quickly climbed towards the canopy. 


\section{$\underline{\text { Localities in secondary forests and rural settlements }}$}

(8) 21 November 2010 at Mont Paramana (0448'30"N; 52²0'19"W; municipality of Matoury): the house cat of Benoit and Melanie Hurpeau caught a juvenile (deciduous third premolar; fourth molar unerupted) female, which was then preserved as voucher (specimen MHNG1990.025). Mont Paramana is a rural settlement of family houses with their gardens surrounded by highly degraded forest patches.

(9) 8 October 2011 at Saint-Georges de l'Oyapock, in a clearing at the edge of secondary forest (0351'27"N; 5149'33"W) near the bridge linking French Guiana to Amapá (Brazil): a single individual was observed and photographed by a police officer (Claude Michoneau). Identification was verified by examining photographs taken by officer Michoneau. Apparently the opossum was climbing on the outside of one of the wooden buildings that shelter the border police and customs officials, and it fell to the ground when the door was suddenly opened.

(10) During the early evening of 20 February 2015, Antoine Baglan and Vincent Premel observed an adult female that was perched at the tip of a leaf of an Astrocaryum-like palm tree along the bank of the Orapu River in the municipality of Roura ( $\left.04^{\circ} 27^{\prime} 57^{\prime \prime} \mathrm{N} ; 52^{\circ} 22^{\prime} 20^{\prime \prime} \mathrm{W}\right)$. The animal was stationary, at a height of about $2 \mathrm{~m}$ above the ground, looking at the source of the beam of the headlights. A. Baglan is well acquainted with the small mammals of French Guiana and is familiar with the diagnostic external traits of Hyladelphys kalinowskii.

(11) 9 March 2015 at Mont Fortuné (0452'51"N; 52²1'05"W; municipality of Matoury): in a landscape of highly degraded secondary forest, small tree thickets, and rural settlements: an adult male was caught by hand in the kitchen of the wooden lodge of Maxime Cobigo, and was photographed by Sebastien Barrioz. 
(12) On 14 March 2015, Sebastien Barrioz found a dead (roadkill) adult male along the main concrete road (N5) between Matoury and Cayenne (04'51'55"N; 52¹8'41"W). This individual was preserved as a specimen (MHNG-1990.002). The surrounding habitat consisted of patches of secondary forest on both sides of the road.

(13) 15 March 2016 at Balata (0452'47"N; 52²0'20"W; municipality of Matoury): in a landscape of highly degraded secondary forest patches and rural settlements: the house cat of Loic Epelboin caught an adult male that was subsequently photographed by Christian Marty. The small opossum was kept in a cage, containing pieces of a peeled fresh orange, on which it fed during the night. The animal escaped at some time during the second day of captivity.

(14) on 15 October 2016 at the Amerindian village of Trois-Sauts (municipality of Camopi), several Wayampi children presented the author with an adult female bearing four very small, naked juveniles (all specimens were preserved with field number ISEM-V-3626). The children had caught these opossums in a hammock on the first floor of a traditional house (see Catzeflis, $2012)$ in the nearby small village called Alamilan $\left(02^{\circ} 15^{\prime} 50^{\prime \prime} \mathrm{N} ; 52^{\circ} 52^{\prime} 07^{\prime \prime} \mathrm{W}\right)$. The locality, on the left bank of the Oyapok River, is surrounded by secondary forest and by slash-and-burn agricultural plots.

To these 14 observations in French Guiana, we can add four specimens already mentioned in the literature:

(15) at Paracou (05¹6'31"N; 5255'25"W; municipality of Sinnamary), Voss et al. (2001: page 39) caught three individuals: one was perched "on a palm frond about $1 \mathrm{~m}$ above the ground in swampy primary forest “ on 25 October 1992, and two other were taken "from the same pitfall trapline, near a small stream in well-drained primary forest” on 21 August 1993. 
(16) along a concrete road between Roura and Kaw $\left(04^{\circ} 31^{\prime} 05^{\prime \prime N}\right.$; 52 $05^{\prime} 43^{\prime \prime} \mathrm{W}$; municipality of Roura) in December 2002, Maël Dewynter caught an adult female that was running across the road, which was bordered at this point by dense primary forest (Astua, 2006). This specimen is preserved with field number ISEM-V-1791 at Montpellier University.

We provide (Table 1) a few external and craniodental measurements for five adult specimens: three from French Guiana (locality 1 = ISEM-V-2632, locality 12 = MHNG-1990.002; and locality 14 = ISEM-V-3626) and two from secondary and/or degraded forests in Brazilian Amapa: specimen IEPA-3501 collected by Claudia Regina da Silva along road BR-156, ca. 15 km from Laranjal do Jari municipality (0048'25"S; 52²9'26"W); and specimen IEPA-1049, collected by Dayse S. Ferreira at Nova Canaa, near Porto Grande municipality $\left(00^{\circ} 42^{\prime 25} \mathrm{~N}\right.$; $\left.51^{\circ} 25^{\prime} 16^{\prime \prime} \mathrm{W}\right)$.

\section{$\underline{\text { Discussion }}$}

The accompanying map (Figure 7) suggests that Hyladelphys kalinowskii occurs throughout French Guiana, from the northern rural settlements in highly degraded forests (localities 8, 11, 12, and 13) to the large blocks of primary forests in the interior (locality 6), as well as in the remote places of the most southern parts of the country (localities 7 and 14). The observations reported herein demonstrate that $H$. kalinowskii can be found in locations with reduced canopy cover, being captured in second-growth forests and disturbed fragments of habitat. That this species seems to have a tolerance for habitat modification is also evidenced by its presence in and near houses (localities 9 and 11). Furthermore, H. kalinowskii is to be found in very different forested landscapes: swampy to well-drained primary forests; secondary forests along concrete roads or remote rivers; and rural settlements from Amerindian traditional houses to 
newly established lodges in man-made clearings. Thus, this tiny opossum is not as rare as previously thought (Voss and Jansa, 2009).

These haphazard field observations provide the first evidence for nest use by Hyladelphys kalinowskii. Although we have no definitive evidence, we suppose that the five nests that were found (at localities 1 and 3 to 6 ) were built by the adult opossum that inhabited them. All of these nests looked quite fresh in appearance; when asked, the observers (all intimately familiar with the local vertebrate fauna) ruled out the possibility that they were co-opted bird's nests. The observers noted on four occasions (localities 1, 3, 4 and 5) that the components of these nests were glued to each other and also to some parts of the nest support, but the origin of the whitish cement used in nest construction (Figure 3) is unknown. Also, the inspection of the various photographs available for the five nests indicates that four of these nests are almost exclusively composed of dry leaves (entire tree-leaves or fragments of) whereas one nest (locality 6: primary forest near Saul) is made of both dry leaves on the inside and shredded bark on the outside (Figure 6). The heights of the five nests (and of the nest box from locality 2) range between 1.0 and $3.0 \mathrm{~m}$ above the ground (average height $=1.8 \mathrm{~m}$ ), which indicates that the species has an arboreal lifestyle, at least in the understory. Whereas two nests contained solitary adults, four others each contained a single adult with 1 to 4 juveniles. There is one observation (june 2009 at Les Nouragues) with four similar-sized full-grown animals sleeping in a nest box, which opens the possibility for some gregarious denning, as observed by Astua et al. (2015) for a few species of Didelphidae.

The use of artificial nest-boxes by didelphid opossums has previously been mentioned for Gracilinanus microtarsus. Tubelis (2000) found lactating female G. microtarsus using bamboo nest boxes on several occasions, and this species also uses tree hollows (Caceres and Pichorim, 2003). More recently, Loretto and Vieira (2011), through the systematic use of a large number of artificial nests, have recorded five species of Didelphidae in such nest-boxes in an Atlantic 
forest site near Rio de Janeiro (Brazil). Like Hyladelphys, nests built by G. microtarsus are composed mainly of dry leaves and have a central chamber where individuals rest (Caceres and Pichorim 2003). For Cryptonanus chacoensis, Canevari and Vaccaro (2007) reported that nests are built from grasses and vegetable fibres in low bushes or tree holes at a height of about 1.5 m. For the species Marmosa paraguayana, Prevedello et al (2009) recorded 9 nests in the crowns of epiphytic bromeliads (similar to our finding in the bromeliad Vriesea splendens), 5 nests in palm-trees (at $6 \mathrm{~m}$ above the ground, on average) and a single roost in a termite nest. Via radio-tracking, Moraes and Chiarello (2005) found 58 nests of M. paraguayana in the Brazilian state of Rio de Janeiro and noticed a distinct preference for roosting in spiny palmtrees of the genus Astrocaryum (as at localities 1 and 4 in this study).

When considering the published observations for French Guiana (3 individuals in Voss et al., 2001; one in Astua, 2006), there is a sample size of 18 Hyladelphys. Animals were observed throughout most of the year (there is no observation in January, April, July, and September). There seems to be slightly less observations during the dry season (August to November: $\mathrm{N}=7$ ) than during the rainy season (December to July: $\mathrm{N}=11$ ), but that probably reflects the intensity of the field activity of observers.

Females with suckling juveniles were observed on 6 occasions: twice with very young (naked) juveniles (in October and December), and four times with older (fully haired) juveniles in February, March, May, and October. Thus, there is no clear indication of reproductive seasonality in these data. Finally, there are four males for which the blue colour of the scrotum can be ascertained (photographs and/or preserved specimen in localities 1; 11 to 13), confirming the observation of Voss et al. (2001: page 32) for one Paracou animal.

The genus Hyladelphys might well include more than one species, as indicated by "high levels of molecular divergence between sequenced specimens of Hyladelphys from French Guiana 
and Peru, together with geographic variation in morphological characters” (Voss and Jansa, 2009: p. 100). As already noted by Voss et al. (2001: pages 33-34), the adult Peruvian specimens seem slightly larger than French Guianan material, and our new data give a better knowledge of the range of sizes in adults from the Guianan Shield countries.

\section{Acknowledgements}

Many thanks to the observers and to the photographers who not only offered these fascinating data but also answered my numerous questions regarding their good fortune: by alphabetical order Antoine Baglan, Sébastien Barrioz, Yann Chavance, Marguerite Delaval, Maël Dewynter, Cyrille D’Haese, Loic Epelboin, Antoine Fouquet, Philippe Gaucher, Benoit and Melanie Hurpeau, Christian Marty, Claude Michoneau, Christian Moulin, Rémy Pignoux, and Vincent Premel. Benoit de Thoisy was helpful in providing temporary hospitality in his freezers for some Hyladelphys specimens collected in French Guiana. I wish to warmly thank Claudia Regina da Silva for hosting me during a pleasant sojourn at Macapa (Amapa: Brazil) for examining specimens kept under her care in the IEPA collections. The discussions with, and the suggestions made by Nilton Caceres have been much appreciated. With his usual generosity, Rob Voss offered his kind assistance for polishing the English and improving the precision of this manuscript. Part of this research belongs to the project “Guyamazon II: Biodiversidade e zoogeografia de pequenos mamíferos no escudo das Guianas “ which was funded by Ambassade de France in Brazil, IRD / AIRD (France), the French Guianan Region, CIRAD, FAPEAM, FAPEMA, and FAPEAP.

This paper is dedicated to the memory of professor Peter Vogel (1942 - 2015), who was my mentor at the Institute of Zoology and Animal Ecology at the University of Lausanne, Switzerland.

\section{References}


Astua, D. 2006. Range extension and first Brazilian record of the rare Hyladelphys kalinowskii (Hershkovitz, 1992) (Didelphimorphia, Didelphidae). Mammalia:174-176.

Astua, D., R. A. Carvalho, P. F. Maia, A. R. Magalhaes, and D. Loretto. 2015. First evidence of gregarious denning in opossums (Didelphimorphia, Didelphidae), with notes on their social behaviour. Biol. Lett. 11: 20150307

Caceres, N. C., and M. Pichorim. 2003. Use of an abandoned mottled piculet Picumnus nebulosus (Aves, Picidae) nest by the Brazilian gracile mouse opossum Gracilinanus microtarsus (Mammalia, Didelphidae). . Biociencias 11:97-99.

Canevari, M., and O. Vaccaro. 2007. Guía de Mamíferos de América del Sur. Editorial L.O.L.A., Buenos Aires.

Catzeflis, F. 2012. A survey of small non-volant mammals inhabiting Wayampi Amerindian houses in French Guiana. Mammalia 76:327-330.

da Silva, C. R., A. C. Moreira Martins, I. J. de Castro, E. Bernard, E. Matos Cardoso, D. Do Santos Lima, R. Gregorin, R. V. Rossi, A. R. Percequillo, and K. d. C. Castro. 2013. Mammals of Amapa state, eastern Brazilian Amazonia: a revised taxonomic list with comments on species distributions. Mammalia 77:409-424.

Hice, C. L. 2001. Records of a few rare mammals from northeastern Peru. Mamm. Biol. 66:317-319.

Jansa, S., and R. Voss. 2005. Phylogenetic relationships of the marsupial genus Hyladelphys based on nuclear gene sequences and morphology. J. Mammal. 86:853-865.

Loretto, D., and M. V. Vieira. 2011. Artificial nests as an alternative to studies of arboreal small mammal populations: a five-year study in the Atlantic Forest, Brazil. Zoologia 28:388-394.

Morães Jr, E. A., and A. G. Chiarello. 2005. Sleeping Sites of Woolly Mouse Opossum Micoureus demerarae (Thomas) (Didelphimorphia: Didelphidae) in the Atlantic Forest of Southeastern Brazil. Revista Brasil. Zool. 22:839-843. 
Prevedello, J. A., R. G. Rodrigues, and E. L. Monteiro-Filho. 2009. Vertical use of space by the marsupial Micoureus paraguayanus (Didelphimorphia, Didelphidae) in the Atlantic Forest of Brazil. Acta Theriol. 54:259-266.

Solari, S., E. Vivar, P. M. Velazco, J. J. Rodríguez, D. E. Wilson, R. J. Baker, and J. L. Mena. 2001. The small mammals of the lower Urubamba region, Peru. Pp. 171-181 in A. Alonso, F. Dallmeier and P. Campbell, eds. Urubamba: the biodiversity of a Peruvian rainforest. Smithsonian Institution Press, Washington, D.C.

Tubelis, D. P. 2000. Aspects on the breeding biology of the gracile mouse opossum Gracilinanus microtarsus in a second growth forest in southeastern Brazil. Papeis Avulsos Zool. 41:173-185.

Voss, R. S., D. P. Lunde, and N. B. Simmons. 2001. The mammals of Paracou, French Guiana: A Neotropical lowland rainforest fauna. Part 2: Nonvolant species. Bull. Amer. Mus. Nat. Hist. 263:1-236. 
TABLE:

\begin{tabular}{|c|c|c|c|c|c|}
\hline & IEPA- & IEPA- & ISEM- & ISEM- & MHNG- \\
\hline Sex & 1049 & 3501 & V-2632 & V-3626 & 1990.002 \\
\hline HBL & - & - & 81,0 & 78,0 & 66,5 \\
\hline LT & - & - & 113,0 & 115,0 & 106,0 \\
\hline HF & - & - & 14,0 & 16,0 & 15,0 \\
\hline Ear & - & - & 19,0 & 19,5 & 19,0 \\
\hline CBL & 20,5 & $a$ & 22,3 & 21,1 & 19,5 \\
\hline LM & 4,3 & 4,5 & 4,5 & 4,4 & $\mathrm{~m}$ \\
\hline PB & 6,5 & 6,7 & 7,1 & 7,0 & $\mathrm{a}$ \\
\hline PL & 11,0 & 10,6 & 12,0 & 11,2 & 10,5 \\
\hline LIB & 3,8 & 3,8 & 4,0 & 3,9 & 3,7 \\
\hline ZB & 12,8 & 12,6 & 14,5 & 14,4 & 12,8 \\
\hline Wt & - & - & - & 15,5 & 7,3 \\
\hline
\end{tabular}

$\mathrm{a}=$ broken skull

Table 1: Measurements (mm) and weights (g) of adult specimens of Hyladelphys kalinowskii. Abbreviations: HBL = Length of Head-and-Body, LT = Length of Tail, HF = Length of Hindfoot (includes the claws), Ear = Length of Ear, CBL = Condylobasal Length, $\mathrm{LM}=$ Length of Molars, PB = Palatal Breadth, PL = Palatal Length, LIB = Least Interorbital Breadth, ZB = Zygomatic Breadth, Wt = Weight. The acronyms IEPA, ISEM, and MHNG are defined in Materials and Methods chapter. 
Captions for Figures

Figure 1: nest containing an adult Hyladelphys kalinowskii, taken from a palm-tree. Some external dry leaves are missing, the remaining inner layers contain leaves which are glued to each other. Observation number 1, at Nouragues field station, on 02 May 2009. Photograph courtesy of Cyrille d’Haese.

Figure 2: an adult female Hyladelphys with its well-haired young on the back, as photographed by Sylvain Pincebourde at La Trinite Mountains (observation number 3) on 03 October 2010.

Figure 3: details of a wooden twig of a nest which is glued with white cement to the green leave of the palm tree carrying the roost. Observation number 4, at La Trinité Mountains, on 16 December 2010. Photograph courtesy of Marguerite Delaval.

Figure 4: nest containing an adult Hyladelphys with well-haired juveniles at La Trinité Mountains (observation number 5). The red arrow points to the hidden entrance of the nest, which was built in the center of a bromeliad (Vriesa splendens). Photographed by Antoine Fouquet on 02 May 2013.

Figure 5: close-up of the same nest as in Fig. 3, with an adult Hyladelphys looking at the observer. Notice the several layers of dry leaves, which appeared to be glued to each other. Photographed by Antoine Fouquet on 02 May 2013

Figure 6: nest made of two different components: an external layer of narrow peel-offs of bark and an internal layer of dry leaves. The relatively large nest fell onto the ground due to human disturbance along a narrow trail, near the village of Saül. One adult Hyladelphys (part of its muzzle is visible in the lower right of the nest) with two well haired juveniles on its back was 
then photographed when fleeing the disturbance. Photographed by Rémy Pignoux on 04 March 2014.

Figure 7: map of French Guiana with locations of the observations of Hyladelphys kalinowskii. 1 and 2 for Nouragues Nature Preserve; 3, 4 and 5 for Trinité Mountains Nature Preserve; 6 for trail between Saül and Mont Galbao; 7 for Mitaraka mountaneous area; 8, 11 and 13 for rural settlements near Matoury; 9 for the French side of the bridge over Oyapock River ; 10 for Orapu River near National Road number 2; 12 for the concrete road between Matoury and Cayenne; 14 for Trois-Sauts along the Oyapock River; 15 for Paracou field station (Voss et al., 2001); and 16 for the narrow road between Roura and Kaw (Astua, 2006). 


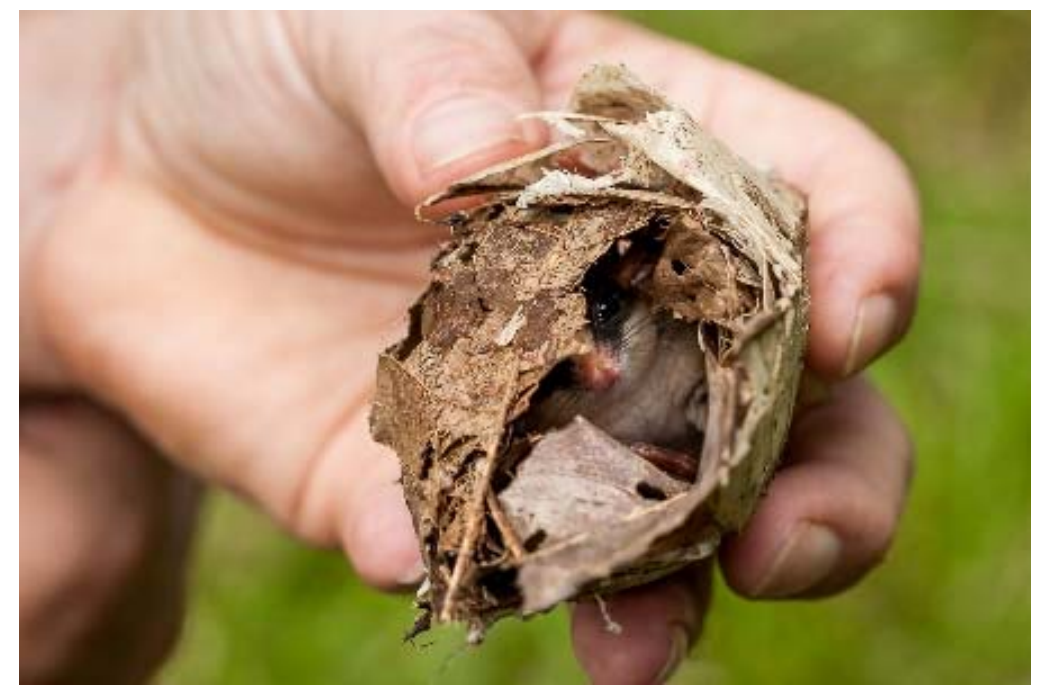

Figure 1

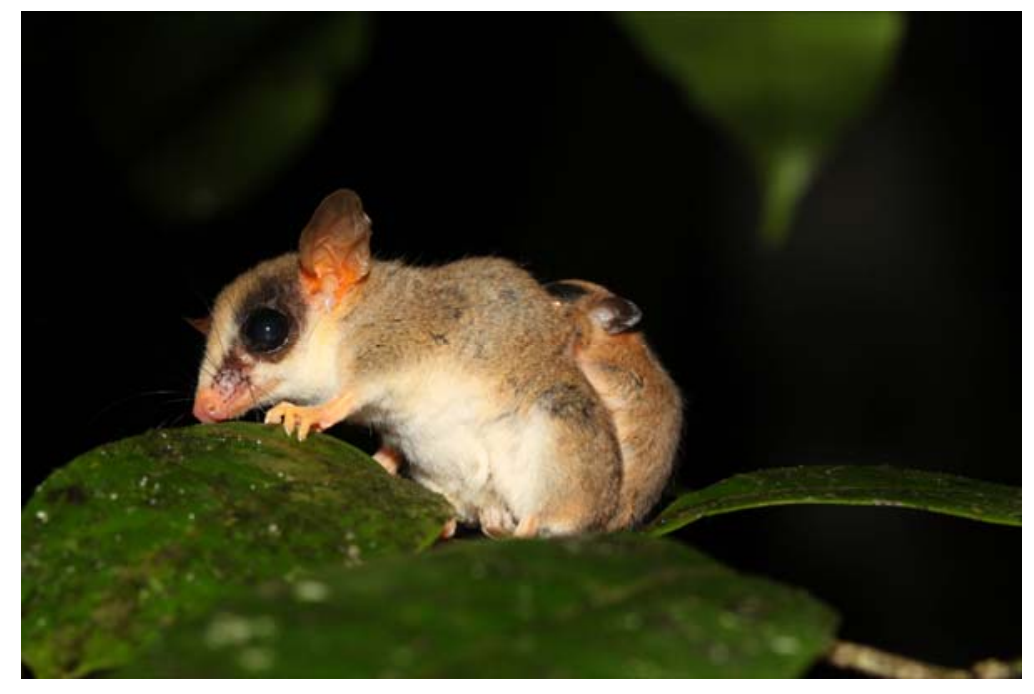

Figure 2

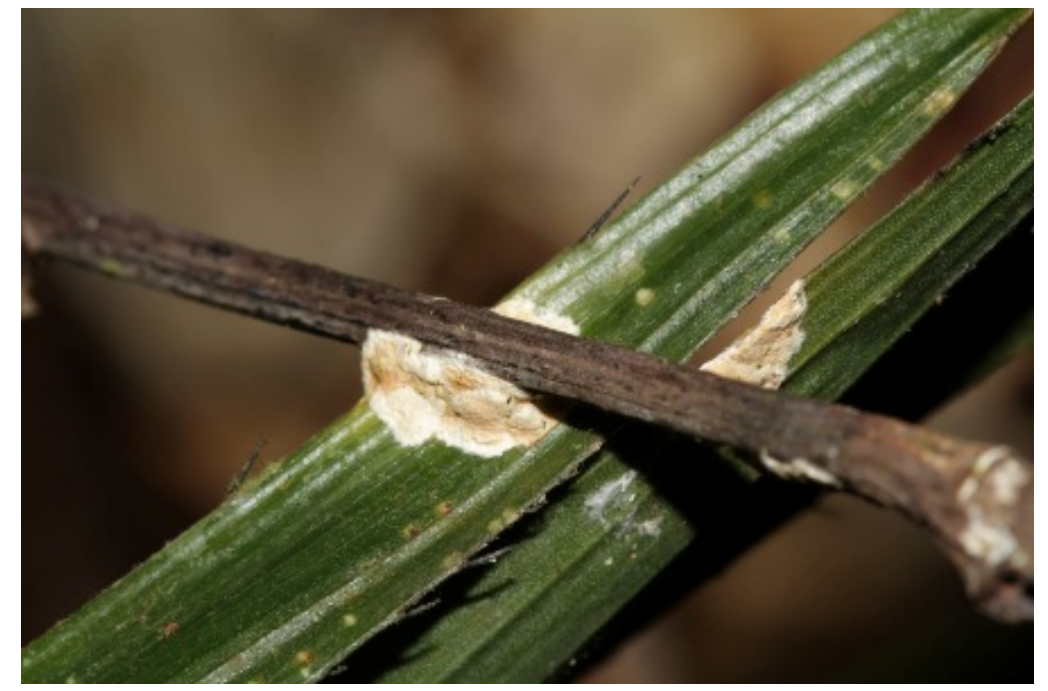


Figure 3

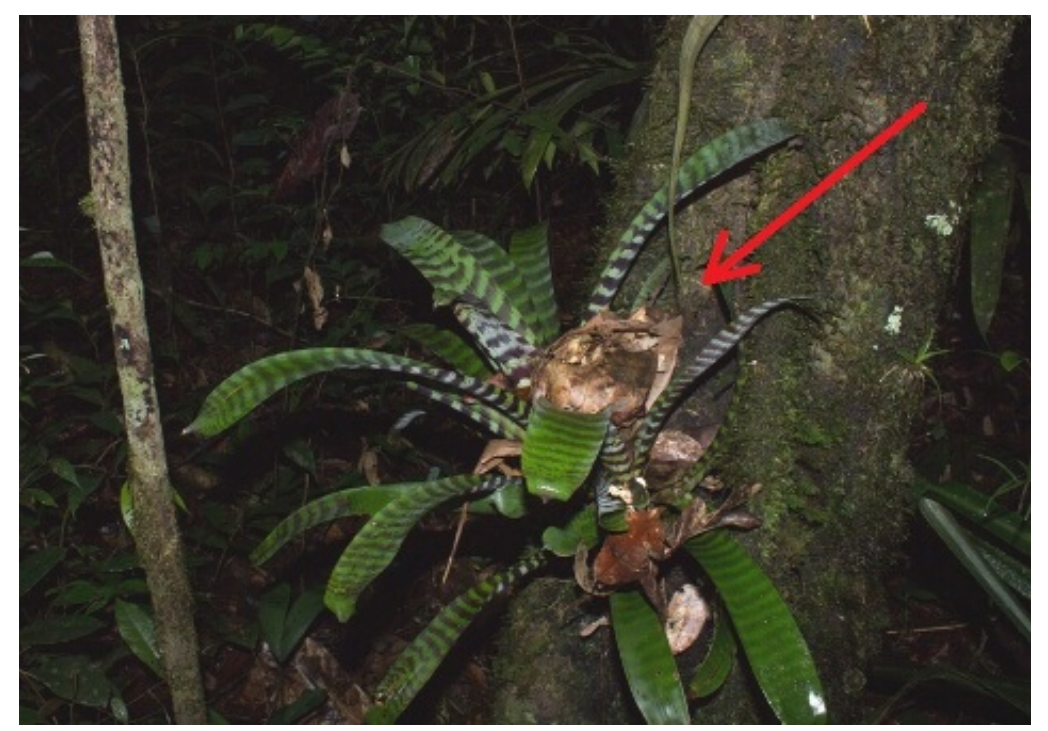

Figure 4

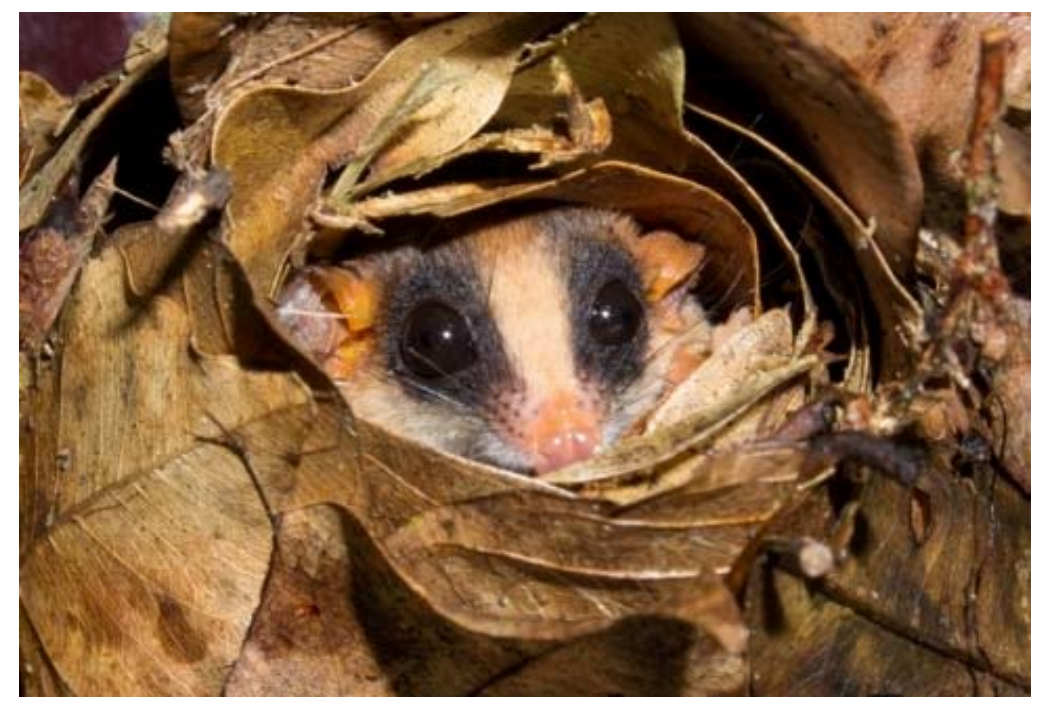

Figure 5 


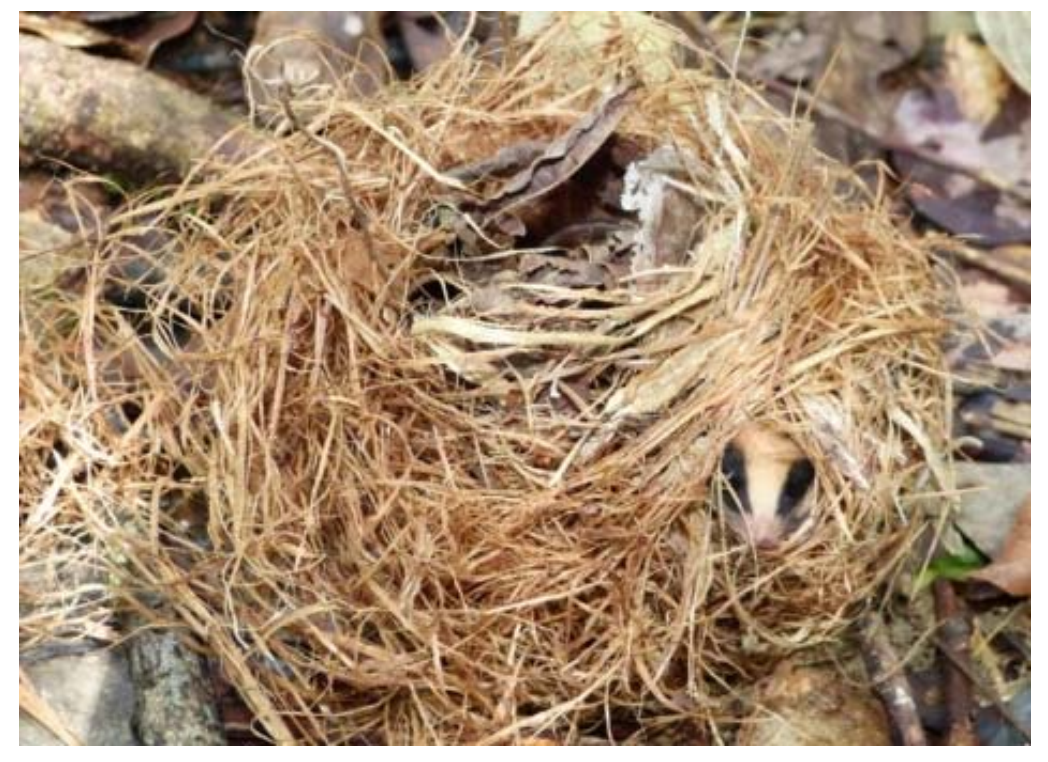

Figure 6

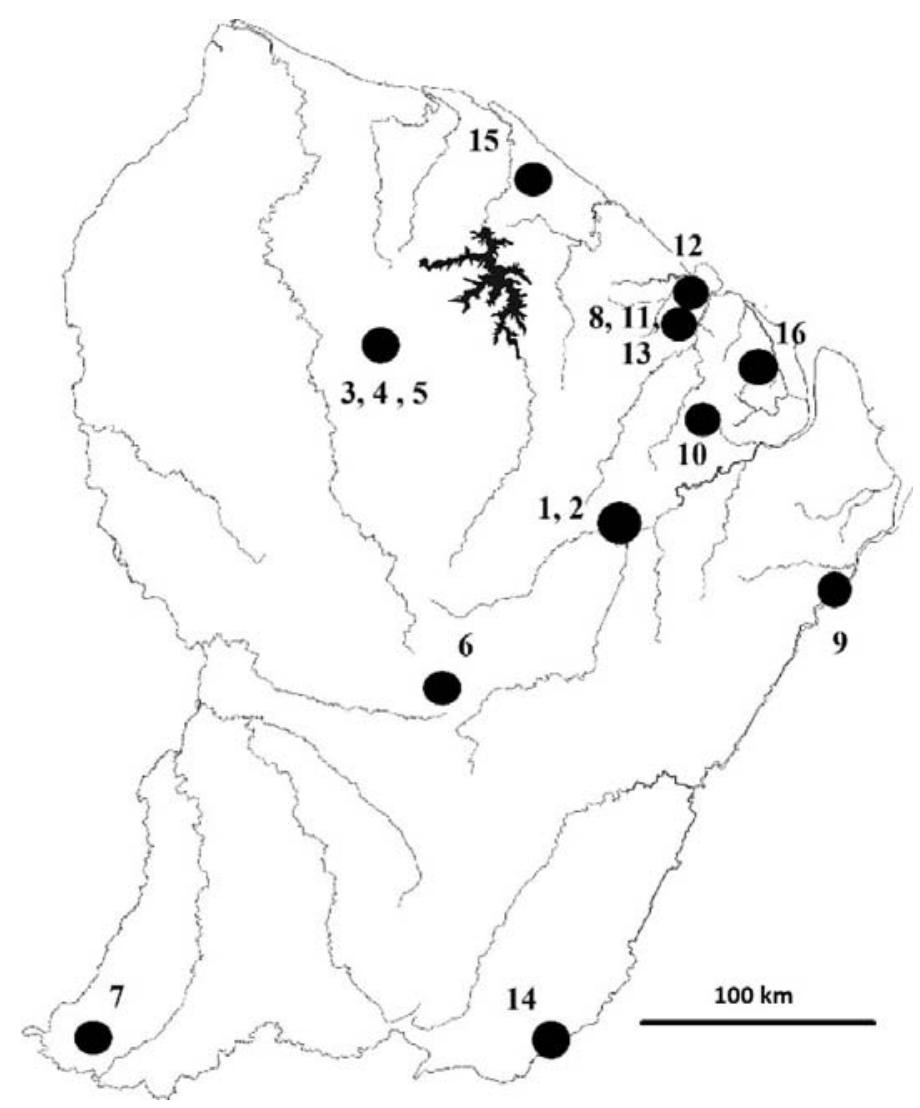

Figure 7 